\title{
ISOLATION AND IDENTIFICATION OF BACTERIA FROM KIDNEY LESIONS IN BROILERS IN SULAIMANIA PROVINCE
}

\author{
AMEEN N.A.; AREF E.D. ${ }^{* *}$; AL-OBAIDI R.M. ${ }^{* * *}$ and RAOOF H.H. ${ }^{* * * *}$ \\ *Dept of Histopathology, College of Veterinary Medicine, Sulaimania University, Kurdistan Region, Iraq \\ *** Dept. of Microbiology, College of Veterinary Medicine, Sulaimania University, Kurdistan Region, Iraq \\ ${ }_{* * * *}^{*}$ Dept. of Basic Sciences, College of Veterinary Medicine, Sulaimania University, Kurdistan Region, Iraq \\ ***** Department of Animal Health, Sulaimania Veterinary Directorate, Ministry of Agriculture and Water Recourses, \\ Kurdistan Region, Iraq \\ Email: nzarameen@yahoo.com \\ Assiut University Email: www.aun.edu.eg
}

\section{ABSTRACT}

Received at: 29/1/2015

Accepted: 24/2/2015

\begin{abstract}
A total of ninety seven broiler chicks in Sulaimania/ Kurdistan region/ Republic of Iraq, were collected from different flocks at different dates suffering from nephritis. Samples of affected kidneys were cultured on blood, Mannitol salt and MacConkey agar plates, the isolates were confirmed by API 20E system. The isolated microorganism included E.coli (89.69\%), Proteus milabilis (9.27\%) and Klebsiella pneumonia (1.03\%). Antimicrobial susceptibility test for E.coli showed high sensitivity to Ciprofloxacin and Co-trimoxazole. Histopathological changes of the kidneys were characterized by enlargement of epithelial cells of renal tubules and pale cytoplasm, engorgement of blood capillaries in both renal glomeruli and interstitial tissues with atrophy of renal glomeruli.
\end{abstract}

Key words: Broiler, Kidney lesions, Bacteria

\section{INTRODUCTION}

Bacteria are pathogenic living organisms but, not all bacteria are detrimental to poultry health. In fact, many bacteria are beneficial and necessary for such processes as food digestion and manufacturing of some dairy products. Classification of bacteria into species is done so disease producing organisms may be separated from those that are harmless or beneficial, (Berry, and Whitenack, 2011).

Bacterial nephritis usually occurs when bacteria enter the kidney secondary to systemic disease through the renal arteries or the renal portal system (Speer, 1997 and Phalen et al., 1990). A wide range of bacteria has been reported to cause bacterial nephritis including Enterobacteriaceae, Pasteurella spp, Pseudomonas spp, Streptococcus spp, and Staphylococcus spp (Speer, 1997, Schmidt et al., 2003, Phalen et al., 1990 and Lierz, 2003). Listeria monocytogenes has been reported (Schmidt et al., 2003), whereas Erysipelothrix rhusiopathiae has been reported in quail and chicken (Schmidt et al., 2003 and Mutalib et al., 1995). Mycobacterium avium can, rarely, cause renal lesions (Schmidt et al., 2003 and Sato et al., 1996).

Among bacterial infections, colibacillosis is a worldwide major cause of morbidity and mortality in poultry and responsible for significant economic losses to the poultry industry, (Stordeur, and Mainil, 2002) they also reported that the causative bacteria, avian pathogenic Escherichia coli (APEC), induce various syndromes including respiratory tract infection (airsacculitis), acute colisepticemia, salpingitis, and cellulitis. The most common form of colibacillosis occurs in 3- to 10-week old chickens. It is characterized by an initial respiratory infection usually induced by mycoplasmal and/or viral infections and enhanced by a high level of ammonia in poultry houses. The disease evolves as a systemic infection (perihepatitis, pericarditis, and septicaemia) due to the invasive abilities of the Escherichia coli strains (Dho-Moulin, and Fairbrother,1999), hence, can infect both kidneys and cause damage to the kidneys and impair its function (Al-Hiyali et al., 2005).

Successful control of bacterial diseases entails isolating and identifying disease-producing species, if present, and preventing multiplication and spread of the organism within the chick's body or to other chicks, also antibacterial resistance has profound clinical implications. The objectives of the present study are to isolate and identify bacterial species infect broiler chicks kidney, furthermore to investigate antibacterial susceptibility and describe 
the changes in the kidneys by means of histopathology.

\section{MATERIALS and METHODS}

A total of ninety seven broiler chicks suffering from nephritis were collected from different flocks in Sulaimania region at different dates. Samples of Affected kidneys were cultured on 5\% blood agar base, Mannitol salt agar, MacConkey agar plates (Quiun et al., 2002) the inoculated plates were incubated at $37 \mathrm{c}^{\circ}$ for $24-48$ hours. Primary cultures were evaluated by visual examination of the morphology of the bacterial colonies and were sub cultured for further examination. The identification of the isolated colonies was performed using standard bacteriological and biochemical procedures as described by carter and Cole (1990) and barrow and felthem (1993) and conformed by API 20E system (biomerieux, Marcy-1 Etoile, france) as per manufactures directions.

Antibacterial susceptibility tests performed to detect the susceptibility of the isolated bacteria to antibiotic which included, Doxycycline 30mg, Ciprofloxacin $5 \mathrm{mg}$, Neomycin 30mg, Ampicillin 10mg, Chloramphenicol 30mg, Co-trimoxazole $25 \mathrm{mg}$ (England) (Brown, 2005).

To study histopathological changes, 1 cubic centimeter size were obtained from the affected kidneys samples of all chicks and kept in $10 \%$ neutral buffered formalin for at least 24 hours. After that, these samples were exposed as described by (james, 1976) for dehydration, clearing, paraffin embedding, blocking, sectioning, mounting and staining with Hematoxylen and Eosin stains and were examined by light microscope.

\section{RESULTS and DISCUSSION}

bacteriological and biochemical tests results showed $89.69 \%$ (87) of isolates were E.coli, $9.27 \%$ (9) isolates were Proteus milabilis and $1.03 \%$ (1) isolates was Klebsiella pneumonia as shown in table (1). The isolates were confirmed by The API 20E test kit (biomerieux, Marcy-1 Etoile, france).

Table 1: Shows bacterial isolates from kidneys samples.

\begin{tabular}{ccc}
\hline Bacteria & Number of isolates & $\%$ \\
\hline E.coli & 87 & 89.69 \\
\hline Proteus milabilis & 9 & 9.27 \\
\hline Klebsiella pneumonia & 1 & 1.03 \\
\hline
\end{tabular}

to conditions such as chronic cloacitis (Speer, 1997, Lierz 2003 and Phalen et al., 1990).

Other bacteria including Proteus mirabilis and Klebsiella pneumonia were isolated out of several kidneys samples but in a lower proportion, mentioned in Table (1), these results were similar to results reported by (Al-Hiyali et al., 2005) in chicken and also similar to results showed by (Quinn et al., 1997) in cattle, buffalo and dog.

In vitro Antimicrobial susceptibility test of the most frequent bacterial Isolates (E.coli isolate) were susceptible to a (Ciprofloxacin and Co-trimoxazole) but showed resistance to (Doxycycline, Ampicillin and -Chloramphenicol) as shown in Table (2) and figure (1), The results of susceptibility testing are identical with those mentioned by Carter and Cole (1990), Carter et al. (1995).
The isolation results of the present study revealed high percentage of E.coli which agree with results mentioned by (Al-Hiyali et al., 2005) and (Sokker et al., 1998), the high percentage of the E.coli isolates $(89.69 \%)$ (Table 1), confirmed the importance of this bacteria for inducing the lesions in kidneys of broiler chicks which is identical to the results of (Al-Hiyali et al., 2005) and (Al- Sultan et al., 1998) in other animals (calves) and also resemble the result revealed by (Al Rajab and Al qazzaz, 1984) in urinary tract infection of human; the explanation of this results is thought due to the absence of lymph nodes and the presence of renal and hepatic portal systems which increase the risk of systemic or gastrointestinal microbes affecting the kidney (Lierz, 2003 and Lumeij 2000), also bacterial nephritis usually occurs when bacteria enter the kidney secondary to systemic diseases through the renal arteries or the renal portal system, Rarely, bacteria ascend the ureters secondary 


\section{Assiut Vet. Med. J. Vol. 61 No. 145 April 2015}

Table 2: Shows Antimicrobial susceptibility test of E.coli isolate in the present study.

\begin{tabular}{cccc}
\hline Antimicrobial agents & Code & Disk potency & Inhibition \\
\hline Doxycycline & DX & $30 \mathrm{mg}$ & $\mathrm{R}$ \\
\hline Ciprofloxacin & $\mathrm{CX}$ & $5 \mathrm{mg}$ & $\mathrm{S}$ \\
\hline Neomycin & $\mathrm{NE}$ & $30 \mathrm{mg}$ & $\mathrm{I}$ \\
\hline Ampicillin & AMP & $10 \mathrm{mg}$ & $\mathrm{R}$ \\
\hline Chloramphenicol & $\mathrm{C}$ & $30 \mathrm{mg}$ & $\mathrm{R}$ \\
\hline Co-trimoxazole & $\mathrm{SXT}$ & $25 \mathrm{mg}$ & $\mathrm{S}$ \\
\hline
\end{tabular}

(S: sensitive, R: resistant, I: intermediate)

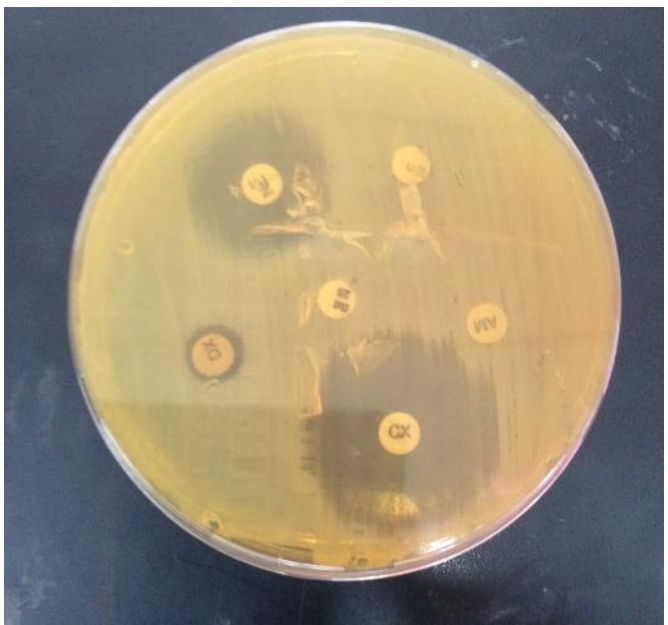

Figure 1: Antimicrobial susceptibility test of E.coli isolate shows susceptible to a (Ciprofloxacin and Cotrimoxazole) but resistant to (Doxycycline, Ampicillin and-Chloramphenicol)

The histopathological examination of affected kidney included the enlargement of epithelial cells of renal tubules with pale cytoplasm, blood capillaries were engorged with large numbers of Red blood cells in both renal glomeruli and interstitial tissues, and congestion of blood vessels in addition to reduction in the size (atrophy) of renal corpuscles as shown in figure (2), the results of histopathological examination of the current study are identical with those mentioned by (Sokker et al., 1998).

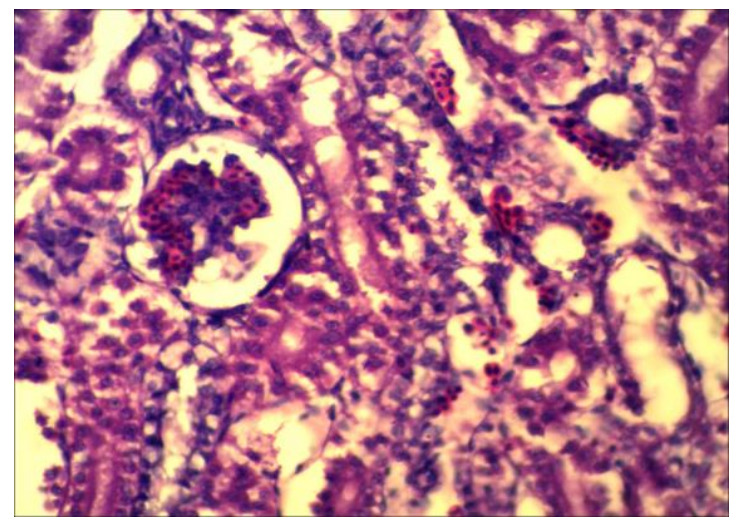

Figure 2: Congestion of blood vessels and atrophy glomeruli (400X)

In conclusion, this work revealed that the E.coli infections are the most real important causes of kidneys lesions leading to economic losses in the broiler chickens thus prevention and control of E.coli infections in broiler farms are very important. 


\section{ACKNOWLEDGMENT}

This work was supported by College of Veterinary Medicine, University of Sulaimania.

\section{REFERENCES}

Al Rajab, Wafaa Jassim Al qazzaz, Hassan Mohamed (1984): Microbiology second edi, Mosul University Press, p. 748.

Al- Sultan, I.I.; Youkhana, S.O. and Ismail, H.K. (1998): Interstitial Renal necrosis syndrome of calves. The Iraqi J. Vet. Med. 22; 35-42.

Al-Hiyali, H.M.; Al-Kabbi, H.T. and Abdulkarim, S. (2005): Isolation of four types of bacteria that cause kidney damage in broiler chickens. The Iraqi J. Vet. Med. Vol 29; 33-42.

Berry, J.G. and Whitenack, D. (2011): Bacterial Diseases of Poultry Excluding Respiratory Diseases, Division of Agricultural Sciences and Natural Resources, Oklahoma State University, Stillwater, Oklahoma at:http://www.osuextra.com.

Brown, A.E. (2005): Microbiological Applications. 9th ed. New York: McGraw- Hill companies; p.221-224.

Carter, G.R. and Cole, J.R. (1990): Diagnostic Procedures in Veterinary Bacteriology and Mycology. 5th Edition. Academic press, Inc. Diego, California.

Carter, G.R.; Chengappa, M.M. and Roberts, A.W. (1995): Essentials of Veterinary Microbiology. $5^{\text {th }}$ Edition. Williams and Wilkins. USA.

Dho-Moulin, M. and Fairbrother, J.M. (1999): Avian pathogenic Escherichia coli (APEC). Vet. Res.; 30: 299-316.

James, J. (1976): Light Microscopic Techniques in Biology and Medicine. Martinus Nijhoff.

Lierz M. (2003): Avian renal disease: pathogenesis, diagnosis, and therapy. Vet Clin North Am Exotic Am Pract; 6: 29-55.

Lumeij, J.T. (2000): Pathophysiology, diagnosis and treatment of renal disorders in birds of prey. In: Lumeij J.T, Remple D, Redig P.T, et al., editors. Raptor biomedicine III. Lake Worth
(FL): Zoological Education Network, Inc; p. 169-78.

Mutalib, A.; Keirs, R. and Austin, F. (1995): Erysipelas in quail and suspected erysipeloid in processing plant employees. Avian Dis; 39(1): 191-3.

Phalen, D.N.; Ambrus, S. and Graham, D.L. (1990): The avian urinary system: form, function, diseases. In: Association of Avian Veterinarians Annual Conference Proceedings. Boca Raton (FL): Association of Avian Veterinarians; p. 44-57.

Quinn, P.J.; Carter M.E.; Markey, B.K. and Carter, C. (1997): ClinicalVeterinary Microbiology. Mosby London.

Quiun, P.J.; Markey, B.K.; Carter, M.E.; Donnelly, W.J. and Leonard, F.C. (2002): Veterinary microbiology and microbial diseases. USA: Blackwell Publishing Company, p.23-26.

Sato, Y.; Aoyagi, T. and Matsuura, S. (1996): An occurrence of avian tuberculosis in hooded merganser (Lophodytes cucullatus). Avian Dis; 40(4): 941-4.

Schmidt, R.E.; Reavill, D.R. and Phalen, D.N. (2003): Urinary system. In: Pathology of pet and aviary birds. Ames (IA): Iowa State Press. p. 95-107.

Sokker, S.M.; Mohammad, M.A. and Atwia, M. (1998): Experimental induction of renal lesion in chickens, Berl. Munch. Tierarztl Wochenschr. 111: 161-163.

Speer, B.L. (1997): Diseases of the urogenital system. In: Altman RB, Clubb SL, Dorrestein GM, et al., editors. Avian medicine and surgery. Philadelphia: WB Saunders; p. 625-44.

Speer, B.L. (1997): Diseases of the urogenital system. In: Altman RB, Clubb SL, Dorrestein GM, et al., editors. Avian medicine and surgery. Philadelphia: WB Saunders; p. 625-44.

Stordeur, P. and Mainil, J. (2002): La colibacillose aviaire. Ann. Méd. Vét.; 146: 11-18.

Styles, D.K.; Phalen D.N. and Clinical avian urology (1998): Seminars in Avian and Exotic Pet Medicine; 7 (2): 104-13.

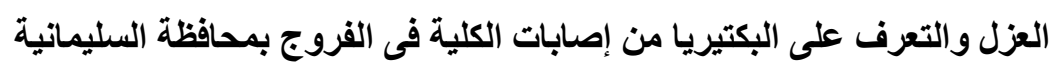

AREF, E.D.; AL-OBAIDI, R.M. and RAOOF, H.H. ، نزار على أمبين

Email: nzarameen@yahoo.com Assiut University Email: www.aun.edu.eg

تم جمع Vو عينة من كلى فروج اللحم المصابة بالتهاب الكلية من أماكن مختلفة لتربية الدواجن وفي فترات مختلفة في مدينة السليمانية/

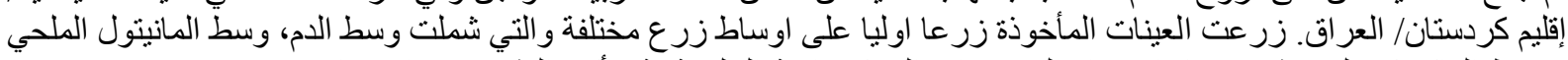

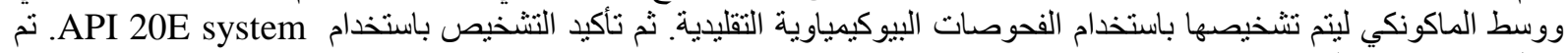

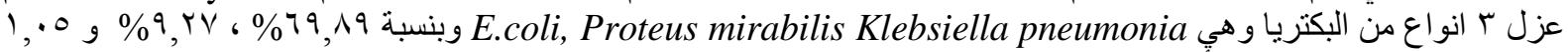

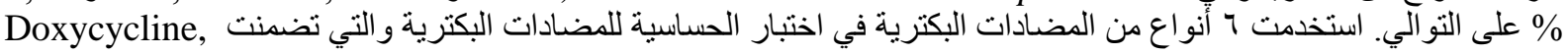
E.coli و Ciprofloxacin, Neomycin, Ampicillin, Chlorumphenicol and Co-trimoxazole حساسيه عاليه لكل من Co-trimoxazole و Ciprofloxacin . شملت التغير ات النسيجية للكلى تضخم الخلايا الطلائية للنبيبات الكلوية مع شحوب السيتوبلازم ، امتلاء وتضخم الأوعية الدموية الشعيرية في كل من الكبيبات الكلوية والأنسجة الخلالية مع ضمور في الكبيبات الكلوية. 